\title{
Current and New Perspectives in the Diagnosis of Blastomycosis and Histoplasmosis
}

\author{
Kathleen A. Linder*(D) and Carol A. Kauffman
}

Infectious Diseases Section, Veterans Affairs Ann Arbor Healthcare System, University of Michigan Medical School, Ann Arbor, MI 48105, USA; ckauff@med.umich.edu

* Correspondence: linderk@med.umich.edu

\begin{abstract}
The diagnosis of blastomycosis and histoplasmosis can be difficult for clinicians who rarely see infections caused by these environmentally restricted dimorphic fungi. Historically, the diagnosis of blastomycosis has been established by culture and sometimes by histopathologic identification. Currently, antigen detection in urine and serum has been shown to aid in the rapid diagnosis of blastomycosis, and newer antibody assays are likely to contribute to our diagnostic capability in the near future. The gold standard for the diagnosis of histoplasmosis has been culture of the organism from involved tissues, aided in some patients by histopathological verification of the typical yeast forms in tissues. Antigen detection has contributed greatly to the ability of clinicians to rapidly establish the diagnosis of histoplasmosis, especially in severely ill and immunocompromised patients, and antibody testing for Histoplasma capsulatum provides important adjunctive diagnostic capability for several forms of both acute and chronic histoplasmosis. For both of these endemic mycoses, novel molecular tests are under active investigation, but remain available in only a few reference laboratories. In this review, we provide a synopsis of diagnostic test options that aid in establishing whether a patient has blastomycosis or histoplasmosis.
\end{abstract}

Keywords: blastomycosis; Blastomyces dermatitidis; histoplasmosis; Histoplasma capsulatum; antigen detection

check for updates

Citation: Linder, K.A.; Kauffman, C.A. Current and New Perspectives in the Diagnosis of Blastomycosis and Histoplasmosis. J. Fungi 2021, 7, 12. https://doi.org/10.3390/jof7010012

Received: 6 December 2020

Accepted: 24 December 2020

Published: 29 December 2020

Publisher's Note: MDPI stays neutral with regard to jurisdictional claims in published maps and institutional affiliations.

Copyright: (c) 2020 by the authors. Licensee MDPI, Basel, Switzerland. This article is an open access article distributed under the terms and conditions of the Creative Commons Attribution (CC BY) license (https: / / creativecommons.org/ licenses/by/4.0/).

\section{Blastomycosis}

Recent advances in taxonomy have established that there are several species in the genus Blastomyces. Blastomyces dermatitidis and Blastomyces gilchristii are closely related organisms that cause indistinguishable clinical disease and have similar epidemiological niches [1]. The differences between these two species can be shown only by analyzing their genetic sequences; phenotypically, they are identical, and clinical laboratories cannot differentiate between them. The geographic distribution of these Blastomyces species includes areas around the Great Lakes, the Mississippi and Ohio River Valleys, and the St. Lawrence seaway. B. gilchristii appears to be the predominant species in several localized regions in northwestern Ontario and northern Wisconsin, where large outbreaks of blastomycosis have occurred [2,3]. For clinical and diagnostic purposes, these can be viewed as the same organism, and we will refer to them both as $B$. dermatitidis throughout this review.

There now are several other species in the genus Blastomyces; these organisms differ from $B$. dermatitidis in both clinical and microbiological aspects. Blastomyces helicus was initially named Emmonsia helica when it was first described in 2015 [4], and a few years later it was transferred to the genus Blastomyces [5]. This organism has been reported to cause disease mostly in immunocompromised patients, including those who have HIV, a hematological malignancy, a solid organ transplant, or are taking immunosuppressive agents; the clinical characteristics of infection differ from those typically seen with blastomycosis [6]. The epidemiology of this species also differs from that of $B$. dermatitidis in that 
cases have been reported from the Western United States and Canada, areas outside the classic endemic region for $B$. dermatitidis. B. helicus differs morphologically from B. dermatitidis in both the mold and yeast phases. The B. helicus yeast forms are smaller than those of $B$. dermatitidis, and cells can have multiple buds. In the mold phase, conidia are absent and hyphae can form characteristic spirals under some conditions [6].

Blastomyces percursus is another newly described dimorphic fungus placed in the Blastomyces genus [7]. The epidemiology of this species differs from that of B. dermatitidis in that infection has been reported to date only in a few patients living in Africa and the Middle East. The mold phase differs from that of $B$. dermatitidis, but the yeast phase of these two species appears similar in tissues [5,7].

The latest addition to the Blastomyces genus was added in 2018. The environmental mold Emmonsia parva has been reclassified as Blastomyces parvus [8]. This organism is dimorphic, as are all Blastomyces species; it does not form yeast-like organisms in tissues, but rather large, swollen, structures called adiaspores [9]. This organism, although genetically related, does not cause the typical clinical picture seen with blastomycosis, but instead causes adiaspiromycosis, a rare granulomatous pulmonary infection [10].

Because these organisms are so uncommon, the atypical Blastomyces species should only rarely be entertained as a diagnostic possibility, and even then only when the patient has not been in an area known to harbor B. dermatitidis or when the histopathology or culture information are not typical for $B$. dermatitidis. The discussion on diagnosis that follows will focus only on $B$. dermatitidis.

\section{Diagnosis of Blastomycosis}

The diagnosis of blastomycosis relies primarily on the standard methods of culture and histopathology, combined with a history of possible exposure to this environmental fungus [11-13]. Antigen testing has proved useful for diagnosis, but antibody assays have been notoriously insensitive and nonspecific. Molecular techniques have had some use, but remain non-standardized.

\subsection{Culture}

The definitive diagnosis of blastomycosis remains the isolation of $B$. dermatitidis in culture. If disease is primarily pulmonary, sputum can provide an adequate sample for culture for some patients, but bronchoalveolar lavage (BAL) fluid is more likely to yield the organism. When skin lesions are present, culture of biopsy material will often yield the organism. Dissemination to sites other than the skin is less common, but in some patients, material for culture can be obtained from biopsy of prostate, bone, or other involved tissue or from the aspiration of synovial fluid. Patients who have central nervous system symptoms should have cerebrospinal fluid (CSF) cultured, but the yield is low [14].

Material from any of the sources noted above should be placed on Sabouraud's dextrose agar, kept at room temperature for 4 to 6 weeks, and assessed for growth of a white or tan mold. Once growth occurs, a commercially available chemiluminescent labeled DNA probe (AccuProbe, Hologic Inc., San Diego, CA, USA) that hybridizes to rRNA of $B$. dermatitidis can quickly confirm the identity of the organism. Not surprisingly, B. gilchristii tests positive with this probe, and also B. helices [6]. Additionally, Emergomyces canadensis and Paracoccidioides brasiliensis, two other dimorphic environmental fungi, can test positive with this probe, but have different morphologic appearances than Blastomyces [15,16]. Rarely encountered fungi, such as Gymnascella hyalinospora and Spiromastigoides asexualis, also can give false positive tests with the DNA probe $[17,18]$.

\subsection{Histopathology and Cytology}

The yeast or tissue form of $B$. dermatitidis is quite distinctive, allowing a diagnosis of proven blastomycosis before the culture has yielded growth of the organism under the most recent European Organization for Research and Treatment of Cancer and the Mycoses Study Group Education and Research Consortium (EORTC/MSGERC) consensus guidelines [19]. 
This approach allows earlier diagnosis and definitive treatment, which is especially important in severely ill patients. The distinctive yeast form is thick-walled, relatively large (typically $8-15 \mu \mathrm{m}$ ), and has a single budding daughter cell that is attached to the mother cell by a broad base. Because of the size, these structures can sometimes be seen on hematoxylin and eosin staining, but definite delineation of the organism always should be sought by staining tissues with a methenamine silver stain or periodic acid-Schiff (PAS) stain. When fluid is obtained for diagnostic purposes, B. dermatitidis is best seen with a calcofluor white stain or in cytological preparations stained with Papanicolaou stain [12]. In general, the tissue response in patients with blastomycosis is pyogranulomatous; if skin is involved, pseudoepitheliomatous hyperplasia is characteristic.

\subsection{Antibody Testing}

Standard immunodiffusion (ID) and complement fixation (CF) assays that are useful for the diagnosis of histoplasmosis have not proved to be sensitive or specific enough to aid in the diagnosis of blastomycosis [20,21]. Further refinements that focused on measuring the antibody response to the WI-1 (BAD-1) adhesion antigen appeared to be more promising [22]. An enzyme immunoassay (EIA) targeting the BAD-1 surface protein offered higher sensitivity and specificity than prior assays [23]. Initial reports with this new assay noted a sensitivity of $88 \%$, and specificity was $99 \%$; however, this was a comparison with serum from patients who either did not have a fungal infection or were healthy controls. When serum samples from patients with histoplasmosis were tested, positive results were found in 3 of 50 samples. Confirmation of sensitivity and specificity await larger studies using this antibody assay.

\subsection{Antigen Detection}

An enzyme immunoassay that detects galactomannans in the cell wall of $B$. dermatitidis (MiraVista Diagnostics, Indianapolis, IN, USA) is available in the United States [24,25]. This assay can be used to test urine, serum, BAL fluid, and CSF [26-28]. Most data on sensitivity and specificity are reported for urine, for which the sensitivity has varied from $76 \%$ to $90 \%$ in different reports [24,27-29]. The test is less sensitive in serum, varying from $56 \%$ to $82 \%$ [25,27,28]; pretreatment with EDTA and heating increases the sensitivity [25]. Sensitivity for antigen detection in BAL fluid and CSF are not known, but have been reported to aid in diagnosis in individual cases [26].

The assay appears highly specific for endemic mycoses, but because many endemic fungi share galactomannan cell wall antigens, the specificity for individual genera is very low. For example, cross-reactivity between the cell wall antigens of $H$. capsulatum and B. dermatitidis is reported to be $93-96 \%$ using this assay [24,25]. Although several patients with blastomycosis have been reported to have false positive antigen tests for Aspergillus galactomannan, no patients with aspergillosis have been reported to have a positive antigen assay for B. dermatitidis [30,31].

Several authors have suggested that following antigen levels in urine can be useful for monitoring the resolution or progression of infection [28,32,33]. In dogs treated for blastomycosis, a decrease in both urine and serum antigen levels has been associated with clinical improvement [34].

\subsection{Nucleic Acid Tests}

Polymerase chain reaction (PCR) has been used infrequently as an aid in the diagnosis of blastomycosis. PCR is very specific and can confirm the diagnosis of blastomycosis, particularly in cases where blastomycosis and histoplasmosis are both possible. However, PCR assays are not standardized or generally available. A few reference laboratories offer PCR testing for B. dermatitidis using assays developed by those institutions [35]. An assay that targets the $B A D 1$ adhesin gene has proved to have high sensitivity and specificity when used to test environmental samples, paraffin-embedded tissues from dogs with blastomycosis, and a small number of human tissue samples [36-38]. It is likely that 
molecular techniques will eventually become more standardized and may become useful rapid assays for blastomycosis.

\section{Histoplasmosis}

Histoplasmosis is caused by fungi of the genus Histoplasma; the most common is Histoplasma capsulatum var. capsulatum (hereafter referred to as $H$. capsulatum). This fungus can be found worldwide, but the highest rates of exposure are found in North and Latin America [39]. In North America, the highest exposure rates occur in the Ohio and Mississippi river valleys, as shown by skin testing with histoplasmin [40,41]. In Latin America, areas with high exposure rates include southern Mexico, Central America, and northern South America. Histoplasma capsulatum var. duboisii has a much more limited geographic distribution, occurring mostly in Central and West Africa, where it coexists with H. capsulatum [42].

Most patients who are exposed to $H$. capsulatum do not develop disease. A small percentage develop acute pulmonary histoplasmosis, which manifests with fevers, malaise, dry cough, patchy pulmonary infiltrates, and lymphadenopathy [43]. Immunocompromised patients, including those with advanced HIV or following organ transplantation, often develop severe pulmonary infection or widespread disseminated infection [44,45].

\section{Diagnosis of Histoplasmosis}

\subsection{Culture}

The gold standard for the diagnosis of histoplasmosis is the recovery in culture of H. capsulatum from a clinical specimen. Growth of Histoplasma may take as long as 6 weeks. Initial growth appears as a white-tan colony at $25^{\circ} \mathrm{C}$ on Sabouraud's dextrose agar. A lactophenol cotton blue preparation will first demonstrate septate hyphae, then eventually microconidia $(2-4 \mu \mathrm{m})$ and the characteristic tuberculate macroconidia $(8-15 \mu \mathrm{m})$. Rarely, mold cultures produce only the smooth walled microconidia and some fail to sporulate. Incubation at $37^{\circ} \mathrm{C}$ causes transformation from the mold phase to the yeast phase. However, transformation to the yeast phase is not needed for definitive identification because a commercially available DNA probe with a chemiluminescent label that binds to $H$. capsulatum rRNA can quickly identify the organism (AccuProbe, Hologic Inc., San Diego, CA, USA). False-positive tests are rare but have been reported with Chrysosporium spp. [46]. Use of matrix-assisted laser desorption ionization time of flight mass spectrometry (MALDIToF MS) technology for organism identification is being studied as an alternative to the use of a DNA probe; identification is possible but due to the infectivity of the organism, this technique may not be viable for clinical laboratories [47].

Although culture is the gold standard, overall sensitivity is low. The yield of H. capsulatum in different forms of histoplasmosis varies tremendously. For example, in mild to moderate pulmonary infection, cultures are often negative, and in central nervous system disease, cultures are rarely positive [43,48]. Additionally, commensal organisms frequently overgrow cultures from specimens taken from the respiratory tract [43].

$H$. capsulatum can be grown from blood, but only rarely when conventional blood culture systems are used and not within the time period of 5 days that blood culture bottles are typically incubated; the average time to growth of $H$. capsulatum in cultures of blood is between 12 to 15 days [49]. The use of a lysis-centrifugation system greatly improves detection from blood [49-51]. Hyphal forms and large bizarre yeast forms, rather than typical small oval yeasts, can be seen on smears made from blood cultures.

\subsection{Histopathology and Cytology}

On histopathology of a tissue specimen, $H$. capsulatum appears as a $2-4 \mu \mathrm{m}$ narrowbased budding yeast when methenamine silver or PAS stains are used. It is poorly seen on Gram stain [52]. For bone marrow specimens or touch preparations, a Giemsa stain is very helpful to show the yeast forms. Similar to blastomycosis, the organism is distinctive enough to allow for a diagnosis of proven histoplasmosis by the EORTC/MSGERC consensus guidelines [19]. The organisms are typically intracellular, but have also been noted in 
extracellular spaces. The species name capsulatum is a misnomer; the original reports of the organism by Samuel Darling in 1906 describe a non-staining area around the organism, hence the name H. capsulatum [53]. H. capsulatum is non-encapsulated, and the "capsule" that was noted was an artifact of tissue processing. Granulomatous inflammation, often with necrosis, is typically seen, except when patients are markedly immunosuppressed, as occurs with advanced AIDS; non-necrotizing or incomplete granulomas may form in these cases when the inflammatory response is impaired. In endovascular infections, particularly endocarditis, atypical and aberrant yeast forms and hyphae are often seen in tissue [54].

\subsection{Antibody Testing}

Antibody testing for H. capsulatum is most helpful after the acute phase of disease, as antibodies can be detected 4-8 weeks after initial infection [55]. Serologic testing is most useful in immunocompetent hosts and is limited in patients who are unable to produce a reliable antibody response, such as those taking immunosuppressive drugs or following solid organ transplantation [44].

Standard antibody assays include both CF and ID. The CF assay tests for both yeast and mycelial (histoplasmin) antibodies [56]. A fourfold increase in either antibody is considered positive; a single value of $\geq 1: 32$ is suggestive of histoplasmosis but is not diagnostic [43]. The ID assay assesses the presence of $\mathrm{H}$ and $\mathrm{M}$ bands $[43,51,56]$. The $\mathrm{H}$ band is seen in $<20 \%$ of cases, rarely without the $\mathrm{M}$ band, and is noted in more severe acute pulmonary or disseminated infection and in chronic forms of histoplasmosis, such as chronic cavitary pulmonary histoplasmosis. The $\mathrm{M}$ band is more commonly seen, appears earlier in the course of infection, and can persist for several years after the $\mathrm{H}$ band has disappeared and infection has resolved.

The CF assay, particularly the yeast phase, is slightly more sensitive than ID for the diagnosis of histoplasmosis; however, sensitivity for both the ID and the CF yeast phase tests has been noted to be as high as $90 \%$ in some studies [56]. The CF mycelial phase antibody is the most specific of the assays but has poorer sensitivity.

Early studies using a more cumbersome radioimmunoassay showed the potential diagnostic benefit of an assay that could measure IgG and IgM antibodies to H. capsulatum [57]. This led to the development of an easily performed EIA to detect IgM and IgG antibodies to H. capsulatum [58]. The sensitivity of this commercially available EIA assay (MiraVista Diagnostics, Indianapolis, IN, USA) is $77-96 \%$ and the specificity is $92 \%$. The EIA test appears to be more sensitive than ID or CF when compared using samples from the same patient. This EIA assay is of special utility in patients with Histoplasma meningitis, in which antibodies to Histoplasma in the cerebrospinal fluid may be the only indication of disease [47]. Cross-reactivity has been noted in patients who have blastomycosis or coccidioidomycosis [58]. Several studies have noted that the combination of the EIA antibody assay and the antigen assay further improves diagnostic accuracy $[47,58]$.

\subsection{Antigen Detection}

The development of antigen testing for histoplasmosis has revolutionized the diagnosis of histoplasmosis. Antigen testing was first developed in the late 1980s using a sandwich radioimmunoassay, which was reformulated into an EIA in 1989. A semi-quantitative second-generation test was developed in 2004 and followed in 2007 by the currently available third-generation, quantitative antigen assay (MiraVista Diagnostics) [59,60]. A second antigen assay using the lateral flow technique has been developed by IMMY Diagnostics (Norman, OK, USA). Testing by MiraVista requires submission of the sample to a central laboratory, but testing with the IMMY platform can be done by individual laboratories, which is useful in settings where processing and shipping samples is not feasible [61,62]. A direct comparison of the sensitivity and specificity of the two assays has not been performed. Rapid antigen testing is of critical importance in areas, such as Latin America, 
in which mortality rates from histoplasmosis are especially high in persons living with HIV / AIDS [45].

Antigen testing is most frequently done on urine or serum specimens and is of highest yield in patients with disseminated histoplasmosis; in this population, antigen is present in the urine in approximately $90 \%$ of patients and in the serum in approximately $80 \%$ of patients [60]. Antigen is less commonly detected in acute pulmonary histoplasmosis; in one report, antigen was positive in urine in only $65 \%$ of patients and in serum in $69 \%$ of patients [63]. Antigen testing is often negative in patients with chronic cavitary pulmonary histoplasmosis and is almost always negative in patients with local complications of histoplasmosis, such as mediastinal granuloma [43]. Antigen testing, particularly in urine, can be used to monitor response to therapy, but some patients who have been successfully treated will show persistence of low concentrations of urinary antigen for many months $[60,64]$. A rise in antigen levels can indicate disease relapse [65]. Histoplasma galactomannans are similar to antigens of other dimorphic fungi, including B. dermatitidis, P. brasiliensis, Talaromyces marneffei, and Sporothrix species, and cross-reactivity of these fungi with the antigen test is common $[66,67]$. This is most clinically relevant for $B$. dermatitidis infection, given overlapping areas of endemicity for these fungi. Aspergillus galactomannan testing also cross-reacts with Histoplasma galactomannans and can be positive in patients with histoplasmosis; patients with aspergillosis do not have false positive Histoplasma antigen [68].

Antigen testing can be performed on other samples, including BAL fluid and CSF [47,69]. It is highly specific and sensitive when CSF is tested in patients with Histoplasma meningitis, in which culture is often negative [47]. Test characteristics are similarly good when used on BAL fluid; in some instances, antigen can be detected in BAL fluid when culture is negative for H. capsulatum [69].

\subsection{Nucleic Acid Tests}

PCR tests have been developed for the detection of $H$. capsulatum but are not often used in clinical care. H. capsulatum rDNA, which is a commonly used target for PCR, is similar to 18-S rDNA of other fungi [70]. This has led to the use of nested PCR, in which multiple primer sets are used. Initial PCR is done for the 18-S rDNA, then PCR is done on that amplified product to detect a more specific product for $H$. capsulatum. Because amplification of an already amplified product occurs, there is an increased risk of contamination [70,71]. Early studies of nested PCR mechanisms testing for both H. capsulatum rDNA and a 100kDa-like protein unique to Histoplasma (later named Hcp100) suggested excellent specificity, although they were limited by DNA extraction capabilities [70]. Subsequent studies have also been done using $\mathrm{N}$-acetylated $\alpha$-linked acidic dipeptidase (NAALAD) and the internal transcribed spacer (ITS) region [72-74]. Sensitivity appears to be highest with PCR of the ITS region in both patients with and without HIV infection; Hcp100 and NAALAD are less reliable $[73,75]$. However, most studies on the use of PCR are small studies done primarily in patients with advanced HIV infection. These data may not be generalizable. PCR testing has not been well validated and is not available for widespread clinical use.

Traditional PCR techniques are not feasible in all settings, on account of their need for specialized equipment and trained operators, and techniques that replicate DNA sequences at a constant temperature may be preferred in resource-limited settings. Loop-mediated isothermal amplification (LAMP) is one such technique that can be completed in one tube and in less than an hour with high selectivity for target DNA [76]. This assay can be modified with the addition of fluorescent markers or dyes to allow easy interpretation $[77,78]$. LAMP methods have been developed for the detection of the Hcp100 locus of H. capsulatum and for ITS $[79,80]$. LAMP of the Hcp100 locus is very specific in laboratory conditions, but less so with clinical specimens [79]. When a positive culture for H. capsulatum is used as the gold standard, LAMP of clinical specimens (bone marrow) had low sensitivity and specificity (54\% and $64 \%$, respectively) [80]. LAMP has the potential to be useful in a low-resource setting, but further data are needed before use of this technique becomes mainstream. 
There is proof of concept that fluorescent in situ hybridization (FISH) targeting Histoplasma rRNA may be clinically useful. One study using in-house probes showed that FISH was equally sensitive and specific to in-house PCR and was able to detect $H$. capsulatum in inoculated blood cultures incubated for only $4 \mathrm{~h}$ as compared with $10 \mathrm{~h}$ with PCR [81]. However, this assay is not currently available for clinical use.

Author Contributions: K.A.L.: resources, writing, review and editing. C.A.K.: resources, writing, review and editing. All authors have read and agreed to the published version of the manuscript.

Funding: This research received no external funding.

Institutional Review Board Statement: Not applicable.

Informed Consent Statement: Not applicable.

Data Availability Statement: Data sharing not applicable.

Conflicts of Interest: Both authors declare that they have no conflict of interest.

\section{References}

1. Brown, E.M.; McTaggart, L.R.; Zhang, S.X.; Low, D.E.; Stevens, D.A.; Richardson, S.E. Phylogenetic analysis reveals a cryptic species Blastomyces gilchristii, sp. nov. within the human pathogenic fungus Blastomyces dermatitidis. PLoS ONE 2013, 8, e59237. [CrossRef]

2. Dwight, P.; Naus, M.; Sarsfield, P.; Limerick, B. An outbreak of human blastomycosis: The epidemiology of blastomycosis in the Kenora catchment region of Ontario, Canada. Can. Commun. Dis. Rep. 2000, 26, 82-91.

3. Thompson, K.; Sterkel, A.K.; Brooks, E.G. Blastomycosis in Wisconsin: Beyond the outbreaks. Acad. Forensic Pathol. 2017, 7, 119-129. [CrossRef]

4. Sigler, L. Emmonsia helica Sigler sp. nov. Index Fungorum 2015, 237, 308.

5. Jiang, Y.P.; Dukik, K.; Munoz, J.F.; Sigler, L.; Schwartz, I.S.; Govendeer, N.P.; Kenyon, C.; Feng, P.; van den Ende, P.G.; Stielow, J.B.; et al. Phylogeny, ecology and taxonomy of systemic pathogens and their relatives in Ajellomycetaceae (Onygenales): Blastomyces, Emergomyces, Emmonsia, Emmonsiellopsis. Fungal Divers. 2018, 90, 245-291. [CrossRef]

6. Schwartz, I.S.; Wiederhold, N.P.; Hanson, K.E.; Patterson, T.F.; Sigler, L. Blastomyces helicus, a new dimorphic fungus causing fatal pulmonary and systemic disease in humans and animals in western Canada and the United States. Clin. Infect. Dis. 2019, 68, 188-195. [CrossRef]

7. Dukik, K.; Munoz, J.F.; Jiang, Y.; Feng, P.; Sigler, L.; Stielow, J.B.; Freeke, J.; Jamailian, A.; van den Ende, B.G.; McEwen, J.G.; et al. A novel taxa of thermally dimorphic systemic pathogens in the Ajellomycetaceae (Onygenales). Mycoses 2017, 60, 296-309. [CrossRef]

8. Peterson, S.W.; Sigler, L. Molecular genetic variation in Emmonsia crescens and Emmonsia parva, etiologic agents of adiaspiromycosis, and their phylogenetic relationship to Blastomyces dermatitidis (Ajellomyces dermatitidis) and other systemic fungal pathogens. J. Clin. Microbiol. 1998, 36, 2918-2925. [CrossRef]

9. Sigler, L. Adiaspiromycosis and other infections caused by Emmonsia species. In Topley and Wilson's Microbiology and Microbial Infections, 10th ed.; Hay, R.J., Merz, W.G., Eds.; Arnold Hodder: London, UK, 2005; pp. 809-824.

10. Borman, A.M.; Jiang, Y.; Dukik, K.; Sigler, L.; Schwartz, I.S.; de Hoog, G.S. Adiaspiromycosis and diseases caused by related fungi in Ajellomycetaceae. In Emerging and Epizootic Fungal Infections in Animals; Seyedmousavi, S., de Hoog, G.S., Guillot, J., Verweij, P.E., Eds.; Springer International Publishing: Cham, Switzerland, 2018; pp. 147-158.

11. Hage, C.A.; Carmona, E.M.; Epelbaum, O.; Evans, S.E.; Gabe, L.M.; Haydour, Q.; Knox, K.M.; Kolls, J.K.; Murad, M.H.; Wengenack, N.L.; et al. Microbiological laboratory testing in the diagnosis of fungal infections in pulmonary and critical care practice. Am. J. Respir. Crit. Care Med. 2019, 200, 535-550. [CrossRef]

12. Saccente, M.; Woods, G.L. Clinical and laboratory update on blastomycosis. Clin. Microbiol. Rev. 2010, 23, 367-381. [CrossRef]

13. Bradsher, R.W.; Bariola, J.R. Blastomycosis. In Essentials of Clinical Mycology, 2nd ed.; Kauffman, C.A., Pappas, P.G., Sobel, J.D., Dismukes, W.E., Eds.; Springer: New York, NY, USA, 2011; pp. 337-348.

14. Kauffman, C.A. Central nervous system Infection with other endemic mycoses: Rare manifestation of blastomycosis, paracoccidioidomycosis, talaromycosis, and sporotrichosis. J. Fungi 2019, 5, 64. [CrossRef] [PubMed]

15. Schwartz, I.S.; Sanche, S.; Wiederhold, N.P.; Patterson, T.F.; Sigler, L. Emergomyces canadensis, a dimorphic fungus causing fatal systemic human disease in North America. Emerg. Infect. Dis. 2018, 24, 758-761. [CrossRef] [PubMed]

16. Padhye, A.A.; Smith, G.; Standard, P.G.; McLaughlin, D.; Kaufman, L. Comparative evaluation of chemiluminescent DNA probe assays and exoantigen tests for rapid identification of Blastomyces dermatitidis and Coccidioides immitis. J. Clin. Microbiol. 1994, 32, 867-970. [CrossRef] [PubMed]

17. Iwen, P.C.; Sigler, L.; Tarantolo, S.; Sutton, D.A.; Rinaldi, M.G.; Lackner, R.P.; McCarthy, D.I.; Hinrichs, S.H. Pulmonary infections caused by Gymnascella hyalinospora in a patient with acute myelogenous leukemia. J. Clin. Microbiol. 2000, 38, 375-381. [CrossRef] [PubMed]

18. Nguyen, M.V.H.; Wiederhold, N.P.; Canete-Gibas, C.; Sanders, C.; Thompson, G.R. Spiromastigoides asexualis as a cause of false-positive Blastomyces DNA probe testing. J. Clin. Microbiol. 2020, 58, e01318-18. [CrossRef] 
19. Donnelly, J.P.; Chen, S.C.; Kauffman, C.A.; Steinbach, W.J.; Baddley, J.W.; E Verweij, P.; Clancy, C.J.; Wingard, J.R.; Lockhart, S.R.; Groll, A.H.; et al. Revision and update of the consensus definitions of invasive fungal disease From the European Organization for Research and Treatment of Cancer and the Mycoses Study Group Education and Research Consortium. Clin. Infect. Dis. 2020, 71, 1367-1376. [CrossRef]

20. Klein, B.S.; Vergeront, J.M.; Kaufman, L.; Bradsher, R.W.; Kumar, U.N.; Mathai, G.; Varkey, B.; Davis, J.P. Serological tests for blastomycosis: Assessments during a large point-source outbreak in Wisconsin. J. Infect. Dis. 1987, 155, 262-268. [CrossRef]

21. Soufleris, A.J.; Klein, B.S.; Courtney, B.T.; Proctor, M.E.; Jones, J.M. Utility of anti-WI-1 serological testing in the diagnosis of blastomycosis in Wisconsin residents. Clin. Infect. Dis. 1994, 19, 87-92. [CrossRef]

22. Klein, B.S.; Jones, J.M. Isolation, purification, and radiolabeling of a novel 120-kD surface protein on Blastomyces dermatitidis yeasts to detect antibody in infected patients. J. Clin. Investig. 1990, 85, 152-161. [CrossRef]

23. Richer, S.M.; Smedema, M.L.; Durkin, M.M.; Brandhorst, T.T.; Hage, C.A.; Connolly, P.A.; Leland, D.S.; Davis, T.E.; Klein, B.S.; Wheat, L.J. Development of a highly sensitive and specific blastomycosis antibody enzyme immunoassay using Blastomyces dermatitidis surface protein BAD-1. Clin. Vaccine Immunol. 2014, 21, 143-146. [CrossRef]

24. Durkin, M.; Witt, J.; Lemonte, A.; Wheat, B.; Connolly, P. Antigen assay with the potential to aid in diagnosis of blastomycosis. J. Clin. Microbiol. 2004, 42, 4873-4875. [CrossRef] [PubMed]

25. Connolly, P.; Hage, C.A.; Bariola, J.R.; Bensadoun, E.; Rodgers, M.; Bradsher, R.W.; Wheat, L.J. Blastomyces dermatitidis antigen detection by quantitative enzyme immunoassay. Clin. Vaccine Immunol. 2012, 19, 53-56. [CrossRef] [PubMed]

26. Bariola, J.R.; Perry, P.; Pappas, P.G.; Proia, L.; Shealey, W.; Wright, P.W.; Sizemore, J.M.; Robinson, M.; Bradsher, R.W., Jr. Blastomycosis of the central nervous system: A multicenter review of diagnosis and treatment in the modern era. Clin. Infect. Dis. 2010, 50, 797-804. [CrossRef]

27. Bariola, J.R.; Hage, C.A.; Durkin, M.; Bensadoun, E.; Gubbins, P.O.; Wheat, L.J.; Bradsher, R.W., Jr. Detection of Blastomyces dermatitidis antigen in patients with newly diagnosed blastomycosis. Diagn. Microbiol. Infect. Dis. 2011, 69, 187-191. [CrossRef]

28. Frost, H.M.; Novicki, T.J. Blastomyces antigen detection for diagnosis and management of blastomycosis. J. Clin. Microbiol. 2015, 53, 3660-3662. [CrossRef] [PubMed]

29. Baumgardner, D.J. Use of antigen testing for Blastomyces in an integrated health system. J. Patient Cent. Res. Rev. 2018, 5, 176-182. [CrossRef] [PubMed]

30. Van Der Veer, J.; Lewis, R.J.; Emtiazjoo, A.M.; Allen, S.D.; Wheat, L.J.; Hage, C.A. Cross-reactivity in the Platelia Aspergillus enzyme immunoassay caused by blastomycosis. Med. Mycol. 2012, 50, 396-398. [CrossRef] [PubMed]

31. Cummings, J.R.; Jamison, G.R.; Boudreaux, J.W.; Howles, M.J.; Walsh, T.J.; Hayden, R.T. Cross-reactivity of non-Aspergillus fungal species in the Aspergillus galactomannan enzyme immunoassay. Diagn. Microbiol. Infect. Dis. 2007, 59, 113-115. [CrossRef]

32. Mongkolrattanothai, K.; Peev, M.; Wheat, L.J.; Marcinak, J. Urine antigen detection of blastomycosis in pediatric patients. Ped. Infect. Dis. J. 2006, 25, 1076-1078. [CrossRef] [PubMed]

33. Tarr, M.; Marcinek, J.; Mongkolrattanothai, K.; Burns, J.L.; Wheat, L.J.; Durkin, M.; Ismail, M. Blastomyces antigen detection for monitoring progression of blastomycosis in a pregnant adolescent. Infect. Dis. Obstet. Gynecol. 2007, 2007, 089059. [CrossRef]

34. Foy, D.S.; Trepanier, L.A.; Kirsch, E.J.; Wheat, L.J. Serum and urine Blastomyces antigen concentrations as markers of clinical remission in dogs treated for systemic blastomycosis. J. Vet. Intern. Med. 2014, 28, 305-310. [CrossRef] [PubMed]

35. Babady, N.E.; Buckwalter, S.P.; Hall, L.; Le Febre, K.M.; Binnicker, M.J.; Wengenack, N.L. Detection of Blastomyces dermatitidis and Histoplasma capsulatum from culture isolates and clinical specimens by use of real-time PCR. J. Clin. Microbiol. 2011, 49, 3204-3208. [CrossRef] [PubMed]

36. Sidamonidze, K.; Peck, M.K.; Perez, M.; Baumgardner, D.; Smith, G.; Chaturvedi, V.; Chaturvedi, S. Real-time PCR assay for identification of Blastomyces dermatitidis in culture and in tissue. J. Clin. Microbiol. 2012, 50, 1783-1786. [CrossRef] [PubMed]

37. Bialek, R.; Cicera, A.C.; Herrmann, T.; Apenus, C.; Shearn-Bochsler, V.A.; Legendre, A.M. Nested PCR assys for detection of Blastomyces dermatitidis DNA in paraffin-embedded canine tissue. J. Clin. Microbiol. 2003, 41, 205-208. [CrossRef] [PubMed]

38. Burgess, J.W.; Schwan, W.R.; Volk, T.J. PCR-based detection of DNA from the human pathogen Blastomyces dermatitidis from natural soil samples. Med. Mycol. 2006, 44, 741-748. [CrossRef]

39. Scully, M.C.; Baddley, J.W. Epidemiology of histoplasmosis. Curr. Fungal Infect. Rep. 2018, 12, 51-58. [CrossRef]

40. Edwards, L.B.; Acquaviva, F.A.; Livesay, V.T.; Cross, F.W.; Palmer, C.E. An atlas of sensitivity to tuberculin, PPD-B, and histoplasmin in the United States. Am. Rev. Respir. Dis. 1969, 99, 1-132.

41. Manos, N.E.; Ferebee, S.H.; Kershbaum, W.F. Geographic variation in the prevalence of histoplasmin sensitivity. Dis. Chest 1956, 29, 649-668. [CrossRef]

42. Loulergue, P.; Bastides, F.; Baudouin, V.; Chandenier, J.; Mariani-Kurkdjian, P.; Dupont, B.; Viard, J.; Dromer, F.; Lortholary, O. Literature review and case histories of Histoplasma capsulatum var. duboisii infections in HIV-infected patients. Emerg. Infect. Dis. 2007, 13, 1647-1652. [CrossRef]

43. Kauffman, C.A. Histoplasmosis: A clinical and laboratory update. Clin. Microbiol. Rev. 2007, 20, 115-132. [CrossRef]

44. Assi, M.; Martin, S.; Wheat, L.J.; Hage, C.; Freifeld, A.; Avery, R.; Baddley, J.W.; Vergidis, P.; Miller, R.; Andes, D.; et al. Histoplasmosis after solid organ transplant. Clin. Infect. Dis. 2013, 57, 1542-1549. [CrossRef] [PubMed]

45. Diagnosing and Managing Disseminated Histoplasmosis among People Living with HIV; Pan American Health Organization and World Health Organization: Washington, DC, USA, 2020. 
46. Brandt, M.E.; Gaunt, D.; Iqbal, N.; McClinton, S.; Hambleton, S.; Sigler, L. False-positive Histoplasma capsulatum Gen-Probe chemiluminescent test result caused by a Chrysosporium species. J. Clin. Microbiol. 2005, 43, 1456-1458. [CrossRef] [PubMed]

47. Valero, C.; Buitrago, M.J.; Gago, S.; Quiles-Melero, I.; Garcia-Rodriguez, J. A matrix-assisted laser desorption/ionization time of flight mass spectrometry reference database for the identification of Histoplasma capsulatum. Med. Mycol. 2018, 56, 307-314. [CrossRef]

48. Bloch, K.C.; Myint, T.; Raymond-Guillen, L.; Hage, C.A.; Davis, T.E.; Wright, P.W.; Chow, F.C.; Woc-Colburn, L.; Khairy, R.N.; Street, A.C.; et al. Improvement in diagnosis of Histoplasma meningitis by combined testing for Histoplasma antigen and Immunoglobulin G and Immunoglobulin M anti-Histoplasma antibody in cerebrospinal fluid. Clin. Infect. Dis. 2018, 66, 89-94. [CrossRef] [PubMed]

49. Vetter, E.; Torgerson, C.; Feuker, A.; Hughes, J.; Harmsen, S.; Schleck, C.; Horstmeier, C.; Roberts, G.; Cockerill, F. Comparison of the BACTEC MYCO/F Lytic bottle to the isolator tube, BACTEC plus aerobic F/bottle, and BACTEC anaerobic lytic/10 bottle and comparison of the BACTEC plus aerobic F/bottle to the isolator tube for recovery of bacteria, mycobacteria, and fungi from blood. J. Clin. Microbiol. 2001, 39, 4380-4386. [PubMed]

50. Murray, P.R.; Masur, H. Current approaches to the diagnosis of bacterial and fungal bloodstream infections for ICU. Crit. Care Med. 2012, 40, 3277-3282. [CrossRef] [PubMed]

51. Ramanan, P.; Vetter, E.; Milone, A.A.; Patel, R.; Wengenack, N.L. Comparison of BACTEC MYCO/F lytic bottle to the Wampole isolator for recovery of fungal and mycobacterial organisms. Open Forum Infect. Dis. 2016, 3, 1557. [CrossRef]

52. Azar, M.M.; Hage, C.A. Laboratory diagnostics for histoplasmosis. J. Clin. Microbiol. 2017, 55, 1612-1620. [CrossRef]

53. Darling, S.T. A protozoon general infection producing pseudotubercles in the lungs and focal necroses in the liver, spleen, and lymph nodes. JAMA 1906, 46, 1283-1285. [CrossRef]

54. Riddell, J.I.V.; Kauffman, C.A.; Smith, J.A.; Assi, M.; Blue, S.; Buitrago, M.I.; Deresinski, S.; Wright, P.W.; Drevets, D.A.; Norris, S.A.; et al. Histoplasma capsulatum endocarditis: Multicenter case series with review of current diagnostic techniques and treatment. Medicine 2014, 93, 186-193. [CrossRef]

55. Linder, K.A.; Kauffman, C.A. Histoplasmosis: Epidemiology, diagnosis, and clinical manifestations. Curr. Fungal Infect. Rep. 2019, 13, 120-128. [CrossRef]

56. Bauman, D.S.; Smith, C.D. Comparison of immunodiffusion and complement fixation tests in the diagnosis of histoplasmosis. J. Clin. Microbiol. 1975, 2, 77-80.

57. Wheat, J.L.; Kohler, R.B.; French, L.V.; Garten, M.; Kleiman, M.; Zimmerman, S.E.; Schlech, W.; Ho, J.; White, A.; Brahmi, Z. Immunoglobulin M and G histoplasmal antibody response in histoplasmosis. Am. Rev. Respir. Dis. 1983, 128, 65-70. [CrossRef] [PubMed]

58. Richer, S.M.; Smedema, M.L.; Durkin, M.M.; Herman, K.M.; Hage, C.A.; Fuller, D.; Wheat, L.J. Improved diagnosis of acute pulmonary histoplasmosis by combining antigen and antibody detection. Clin. Infect. Dis. 2016, 62, 896-902. [CrossRef]

59. Connolly, P.A.; Durkin, M.M.; LeMonte, A.M.; Hackett, E.J.; Wheat, L.J. Detection of Histoplasma antigen by a quantitative enzyme immunoassay. Clin. Vaccine Immunol. 2007, 14, 1587-1591. [CrossRef]

60. Hage, C.A.; Azar, M.M.; Bahr, N.; Loyd, J.; Wheat, L.J. Histoplasmosis: Up-to-date evidence-based approach to diagnosis and management. Semin. Respir. Crit. Care Med. 2015, 36, 729-745.

61. Caceres, D.H.; Samayoa, B.E.; Medina, N.G.; Tobon, A.M.; Guzman, B.J.; Mercado, D.; Restrepo, A.; Chiller, T.; Arathoon, E.E.; Gomez, B.L. Multicenter validation of commercial antigenuria reagents to diagnose progressive disseminated histoplasmosis in people living with HIV/AIDS in two Latin American countries. J. Clin. Microbiol. 2018, 56, e01959-17. [CrossRef]

62. Nacher, M.; Blanchet, D.; Bongomin, F.; Chakrabarti, A.; Couppie, P.; Demar, M.; Denning, D.W.; Djoussou, F.; Epelboin, L.; Govender, N.; et al. Histoplasma capsulatum antigen detection tests as an essential diagnostic tool for patients with advanced HIV disease in low and middle income countries; a systematic review of diagnostic accuracy studies. PLoS Negl. Trop. Dis. 2018, 12, e0006802. [CrossRef]

63. Swartzentruber, S.; Rhodes, L.; Kurkjian, K.; Zahn, M.; Brandt, M.E.; Connolly, J.; Wheat, L.J. Diagnosis of acute pulmonary histoplasmosis by antigen detection. Clin. Infect. Dis. 2009, 49, 1878-1882. [CrossRef] [PubMed]

64. Hage, C.A.; Kirsch, E.J.; Stump, T.E.; Kauffman, C.A.; Goldman, M.; Connolly, P.; Johnson, P.C.; Wheat, L.J.; Baddley, J.W. Histoplasma antigen clearance during treatment of histoplasmosis in patients with AIDS determined by a quantitative antigen enzyme immunoassay. Clin. Vaccine Immunol. 2011, 18, 661-666. [CrossRef] [PubMed]

65. Wheat, L.J.; Connolly-Stringfield, P.; Blair, R.; Connolly, K.; Garringer, T.; Katz, B.P. Histoplasmosis relapse in patients with AIDS: Detection using Histoplasma capsulatum variety capsulatum antigen levels. Ann. Intern. Med. 1991, 115, 936-941. [CrossRef] [PubMed]

66. Assi, M.; Lakkis, I.E.; Wheat, L.J. Cross-reactivity in the Histoplasma antigen enzyme immunoassay caused by sporotrichosis. Clin. Vaccine Immunol. 2011, 18, 1781-1782. [CrossRef] [PubMed]

67. Wheat, J.; Wheat, H.; Connolly, P.; Kleiman, M.; Supparatpinyo, K.; Nelson, K.; Bradsher, R.; Restrepo, A. Cross-reactivity in Histoplasma capsulatum variety capsulatum antigen assays of urine samples from patients with endemic mycoses. Clin. Infect. Dis. 1997, 24, 1169-1171. [CrossRef] [PubMed]

68. Vergidis, P.; Walker, R.C.; Kaul, D.R.; Kauffman, C.A.; Freifeld, A.G.; Slagle, D.C.; Kressel, A.B.; Wheat, L.J. Falsepositive Aspergillus galactomannan assay in solid organ transplant recipients with histoplasmosis. Transpl. Infect. Dis. 2012, 14, 213-217. [CrossRef] 
69. Hage, C.A.; Davis, T.E.; Fuller, D.; Egan, L.; Witt, J.R.; Wheat, L.J.; Knox, K.S. Diagnosis of histoplasmosis by antigen detection in BAL fluid. Chest 2010, 137, 623-628. [CrossRef]

70. Bialek, R.; Feucht, A.; Aepinus, C.; Just-Nubling, G.; Robertson, V.J.; Knobloch, J.; Hohle, R. Evaluation of two nested PCR assays for detection of Histoplasma capsulatum DNA in human tissue. J. Clin. Microbiol. 2002, 40, 1644-1647. [CrossRef]

71. Vasconcellos, I.C.D.S.; Lana, D.F.D.; Pasqualotto, A.C. The role of molecular tests in the diagnosis of disseminated histoplasmosis J. Fungi 2019, 6, 1. [CrossRef]

72. Dantas, K.C.; Frietas, R.S.; Moriera, A.P.V.; da Silva, M.V.; Benard, G.; Vaconcellos, C.; Criado, P.R. The use of nested polymerase chain reaction (nested PCR) for the early diagnosis of Histoplasma capsulatum infection in serum and whole blood of HIV-positive patients. Ann. Bras. Dermatol. 2013, 88, 141-143. [CrossRef]

73. Muraosa, Y.; Toyotome, T.; Yahiro, M.; Watanabe, A.; Shikanai-Yasuda, M.A.; Kamei, K. Detection of Histoplasma capsulatum from clinical specimens by cycling probe-based real-time PCR and nested real-time PCR. Med. Mycol. 2016, 54, 433-438. [CrossRef]

74. Gago, S.; Esteban, C.; Valero, C.; Zaragoza, O.; Puig de la Bellacasa, J.; Buitrago, M.J. A multiplex real-time PCR assay for identification of Pneumocystis jirovecii, Histoplasma capsulatum, and Cryptococcus neoformans/Cryptococcus gattii in samples from AIDS patients with opportunistic pneumonia. J. Clin. Microbiol. 2014, 52, 1168-1176. [CrossRef]

75. Dantas, K.C.; de Frietas, R.S.; da Silva, M.V.; Criado, P.R.; do Carmo Luiz, O.; Vicentini, A.P. Comparison of diagnostic methods to detect Histoplasma capsulatum in serum and blood samples from AIDS patients. PLoS ONE 2018, 13, e0190408. [CrossRef]

76. Notomi, T.; Okayama, H.; Masubuchi, H.; Yonekawa, T.; Wantanabe, K.; Amino, N.; Hase, T. Loop-mediated isothermal amplification of DNA. Nucleic Acids Res. 2000, 28, E63. [CrossRef]

77. Goto, M.; Honda, E.; Ogura, A.; Nomoto, A.; Hanaki, K.I. Colorimetric detection of loop-mediated isothermal amplification reaction by using hydroxy naphthol blue. BioTechniques 2009, 46, 167-172. [CrossRef]

78. Tanner, N.A.; Zhang, Y.; Evans, T.C. Visual detection of isothermal nucleic acid amplification using pH-sensitive dyes. BioTechniques 2015, 58, 59-68. [CrossRef] [PubMed]

79. Scheel, C.M.; Zhou, Y.; Theodoro, R.C.; Abrams, B.; Balajee, A.S.; Litvintseva, A.P. Development of a loop-mediated isothermal amplification method for detection of Histoplasma capsulatum DNA in clinical samples. J. Clin. Microbiol. 2013, 52, 483-488. [CrossRef] [PubMed]

80. Zatti, M.D.S.; Arantes, T.D.; Fernandes, J.A.L.; Bay, M.B.; Milan, E.P.; Naliato, G.F.S.; Theodoro, R.C. Loop-mediated isothermal amplification and nested PCR of the internal transcribed spacer (ITS) for Histoplasma capsulatum detection. PLoS Negl. Trop. Dis. 2019, 13, e0007692. [CrossRef] [PubMed]

81. Da Silva, R.M.; da Silva Neto, J.R.; Santos, C.S.; Cruz, K.S.; Frickmann, H.; Poppert, S.; Koshikene, D.; Braga da Souza, J.V. Fluorescent in situ hybridization of pre-incubated blood culture material for the rapid diagnosis of histoplasmosis. Med. Mycol. 2015, 53, 160-164. [CrossRef] 